\title{
PROTESTOS E MARCHAS DE MULHERES EM BRASÍLIA: VISUALIDADES E ESTÉTICAS
}

\author{
Luciana Ceschin ${ }^{1}$ \\ Virgínia Tiradentes Souto ${ }^{2}$
}

\section{Introdução}

Protestos e marchas ocorrem ao redor do mundo diariamente. Os sujeitos envolvidos nesses eventos dedicam tempo e energia para atrair a atenção da mídia, que possui um grande poder na geração de opinião sobre um movimento social, seja ela positiva ou negativa. O protesto é a umas das formas mais visíveis sobre os múltiplos conflitos existentes na modernidade e nas democracias, sejam eles de classe, identitários, econômicos, ambientais ou morais (Tarrow, 2009), nas quais os manifestantes se reúnem e encontram oportunidades de compartilhar valores e princípios que podem inspirar e recrutar outras pessoas, ou, causar indignação.

Em um protesto "participantes desenvolvem outras visões primeiro para si mesmos, mas depois as oferecem ao resto de nós" (Jaspers, 2016: 208). Ao criar estratégias para a participação em protestos, os indivíduos utilizam recursos como o desenho, a escrita, a música, a narrativa oral e o corpo. As visualidades e a estética desses eventos transformam a vida pública e o espaço público em palco, trazendo à tona elementos que permitem refletir sobre os problemas sociais que afetam a sociedade de forma desigual, as injustiças e as diferentes perspectivas políticas.

Ao analisarmos imagens de protestos, podemos, por exemplo, diferenciar reivindicações progressistas ou conservadoras, identificar diferentes orientações e ideologias dos diferentes grupos que tomam as ruas. As diversas formas de comunicar e expressar a imaginação política em protestos são, também, formas de se construir alegorias sobre o mundo social. Nesse sentido, as visualidades produzidas nestes eventos podem ser exploradas como uma forma de compreender as relações entre imagem, identidade, política e estética.

\footnotetext{
${ }^{1}$ Universidade de Brasília, Brasil. Email: luceschin@gmail.com ORCID id: https://orcid.org/0000-0001-6279-9485

2 Universidade de Brasília, Brasil. Email: v.tiradentes@gmail.com ORCID id: https://orcid.org/0000-0001-7576-2876
} 
Este artigo tem por objetivo apresentar registros e análises de visualidades produzidas para protestos ou marchas protagonizados por movimentos de mulheres ocorridos na cidade de Brasília entre os anos de 2019 e 2020. Quatro protestos ou marchas foram analisados: a $1^{\mathrm{a}}$ Marcha das Mulheres Indígenas, ocorrida em agosto de 2019; a $1^{\mathrm{a}}$ Marcha das Mulheres Sem Terra e os eventos relacionados ao Dia Internacional da Mulher (8M), que ocorreram simultaneamente em março de 2020; e o protesto intitulado Justiça por Mari Ferrer, que ocorreu em novembro de 2020. Além disso, o artigo identifica e analisa os repertórios visuais e estéticas que fazem parte das escolhas individuais e coletivas entre as pessoas autoconvocadas e grupos organizados.

\section{Visualidade, espaço público, protestos e marchas}

Compreendemos a visualidade como uma prática discursiva para representar e regular o real (Mirzoeff, 2016). Ela não diz respeito apenas aos estímulos visuais ao nosso redor e às diferentes maneiras de nos relacionamos a esses elementos, mas também às formas como produzimos visualmente a realidade. Segundo Mirzoeff (2016), produzir visualidades corresponde a fazer os processos da história perceptíveis à autoridade. Este processo não ocorre apenas de forma física, ele também é formado por um conjunto de relações que combinam informação, imaginação e introspecção. Ao criar estratégias para evitar o ocultamento em meio à multidão e para que o protesto seja visualmente potente, manifestantes elaboram artefatos como cartazes, coreografias, encenações, empunham lenços, portam uma variedade de objetos, escolhem a cor ou tipo de roupa e, dessa forma, colaboram com a produção dessa visualidade e com os significados do evento.

Butler (2018), ao discutir a importância da visualidade de um protesto, tanto aquela que alcança o espectador que está na rua, como a que está nas mídias, afirma que "as cenas das ruas se tornam politicamente potentes apenas quando - e se - temos uma versão visual e audível da cena comunicada" (Butler, 2018: 96). Acerca de como as visualidades agem nesse sentido, a filósofa afirma que algumas imagens operam sobre as pessoas de forma a fazer aquilo que chama de "solicitação ética" (Butler, 2018: 106). Nem sempre podemos decidir sobre o que vai "colidir" visual ou sonoramente conosco, mas, muitas vezes, esses estímulos nos convocam eticamente, nos mostrando outras realidades, pontos de vista e experiências de vida.

Um protesto é, também, uma forma de interpelar visualmente a paisagem das cidades. Os locais escolhidos pelos protestos e marchas não são escolhas aleatórias e estão relacionados aos significados que possuem em respeito ao que se quer enunciar com as 
assembleias públicas. Toda cidade tem lugares em que o poder se inscreve e costumam ser eleitos por manifestantes em um protesto. São lugares-cenários que colaboram com a narrativa e, embora não possa determinar as formas como ocorrerá a recepção pelo público, o ambiente material intensifica, destaca e dramatiza um problema ou uma causa, tornando-o visível e multiplicando a intensidade emocional.

Para Hannah Arendt (2009), o espaço público é o espaço político, lugar da ação, da visibilidade e do discurso. Sua teoria sobre a democracia está fundada no civismo e, para a autora, o espaço público não está amarrado a uma localização específica e sim entre as pessoas. Judith Butler (2018) concorda com Arendt de que o verdadeiro espaço público está na aliança, no entanto, considera que toda ação é apoiada e corporal e, diferente da filósofa alemã, traz o aspecto material como um elemento importante em uma assembleia. Os ambientes materiais são também parte da ação, possuem agência, não configuram apenas como suporte das manifestações.

A performatividade, para Butler (2018), é tanto o processo de ser objeto de uma ação, quanto as condições e possibilidades para a ação. A performatividade plural busca produzir uma fenda na esfera de aparecimento expondo suas contradições em relação à sua suposta universalidade. Ao congregar, mover ou falar juntos, as pessoas reivindicam um determinado espaço como público, transformando um espaço histórico a partir de sua ação coletiva e exercendo um direito plural e performativo de aparecer. As assembleias, nesse sentido, possuem a capacidade de reconfigurar a materialidade do espaço público e, ao mesmo tempo, conferem o caráter público deste ambiente material, construindo diferentes histórias que se contradizem conforme são ocupados e modificados, tensionando discursos normativos acerca desses espaços.

Os protestos revelam o dissenso, apresentam outras formas sensíveis de experiência do mundo. Na definição de Rancière (1996), o dissenso é, antes de ser um conflito de classes ou de partidos, um conflito sobre a configuração do mundo sensível. Para o autor, a democracia não se estabelece mediante o acordo coletivo sobre os rumos da pólis, e sim no estabelecimento de um dissenso entre aqueles que exercem uma determinada dominação em relação aos demais, que são subordinados a este poder. $\mathrm{O}$ dissenso, na concepção do autor, é a tentativa de se instaurar um novo mundo sensível daqueles que não fazem parte, mas que buscam fazer. É a capacidade de invenção na política, em que são criados novos mundos sensíveis e entendimentos sobre o agir político. Para o autor, "a política ocupa-se do que se vê e do que se pode dizer sobre o 
que é visto, de quem tem competência para ver e qualidade para dizer, das propriedades do espaço e dos possíveis do tempo" (Rancière, 2009:17). Os protestos tornam visíveis o que, por vezes, é imperceptível ou invisibilizado, agindo nas sensibilidades, chamam a atenção para outras formas de viver e sentir o mundo.

Em seu texto de apresentação da exposição Levantes, Didi-Huberman (2017) afirma que as manifestações passam a existir, primeiro, no exercício da imaginação das pessoas. Quando confrontadas com algo da realidade que as ameace ou as oprima, a resistência vem de forças que são, “antes de tudo, desejos e imaginações, ou seja, forças psíquicas de desencadeamento e de reaberturas de possibilidades" (Didi-Huberman, 2017: 49). Para o autor sempre existirão aqueles e aquelas que se dispõem à insurreição, nem que seja apenas imaginando, sugerindo que o ato de inventar imagens colabore com a reinvenção das esperanças políticas. A ação de protesto é uma força propulsora que move desejos de fazer coisas, mesmo que haja a possibilidade de fracasso, e que as reivindicações não sejam atendidas. Protestar é, também, viver poeticamente.

\section{Os protestos e marchas dos movimentos de mulheres em Brasília}

Brasília, centro da política nacional, é uma cidade planejada a partir dos princípios da Carta de Atenas $^{3}$, mas embora o plano evocasse uma característica democrática da cidade, ele não foi capaz de provocar mudanças nas formas como a sociedade se organizou ao seu redor ao longo dos seus 60 anos, marcados por extensa migração e ocupação periférica de seu território. De arquitetura imponente, o plano colaborou com a segregação da sociedade e com o aprofundamento das desigualdades.

Os protestos e marchas costumam, em sua maioria, ocupar a região da Esplanada dos Ministérios, iniciando com concentração na área ao redor do Museu Nacional e da Biblioteca Nacional, seguido de marcha pela Esplanada e finalizando na Alameda das Bandeiras, diante do Congresso Nacional. Os carros de som frequentemente estacionam na Alameda, enquanto a multidão pode ocupar o gramado que, como todo o eixo, tem proporções monumentais. O grande vazio, ao mesmo tempo em que comporta uma multidão, faz ela ficar pequena nos registros da mídia, além de ser muito útil para o Estado para observar e controlar as pessoas em assembleia. Por vezes uma marcha alcança a

\footnotetext{
${ }^{3}$ A Carta de Atenas é um manifesto IV Congresso Internacional de Arquitetura Moderna (CIAM), realizado em Atenas em 1933, que defende a funcionalidade das cidades, a atenção às necessidades das pessoas que a habitam e que o território destas devem ser público em sua totalidade.
} 
Praça dos Três Poderes e, quando a intenção dos movimentos é fazer um protesto, sem marcha, este local costuma ser eleito. No entanto, quando os motivos pelo que se insurge diz respeito a questões locais, outros espaços como o Palácio Buriti, sede do governo do Distrito Federal, a Praça Zumbi dos Palmares ou a Rodoviária do Plano Piloto se tornam os cenários mais adequados às pautas. Essa ambivalência entre pautas nacionais e locais nos protestos e marchas faz de Brasília um cenário interessante para o estudo desse tipo de evento.

A $1^{\text {a }}$ Marcha das Mulheres Indígenas, realizada em agosto de 2019, foi parte de um conjunto de ações que contou com acampamento no gramado da Funarte a partir do dia 09 de agosto de 2019, de onde teve início a marcha ocorrida no dia 13 e, posteriormente, também houve a ocupação do prédio da Secretaria Especial de Saúde Indígena (SESAI). No ponto em que a marcha passava ao lado do Museu Nacional, outro evento, o "Tsunami da educação", que se concentrava no local, assistiu a passagem das mulheres e, depois, integrou a marcha, seguiu-a.

Os eventos relacionados ao Dia Internacional da Mulher, ocorrido em 08 de março de 2020, teve concentração e início de marcha no mesmo local onde já estava ocorrendo o $1^{\circ}$ Encontro das Mulheres Sem Terra, no pavilhão do Parque da Cidade. Em conjunto com a $1^{\text {a }}$ Marcha das Mulheres Sem Terra, os movimentos feministas organizados que atuam no Distrito Federal, responsáveis pela coordenação do $8 \mathrm{M}$, e também pessoas autoconvocadas, partiram em marcha até o Palácio do Buriti, sede do governo do Distrito Federal e, de lá, até a Torre de TV, local em que o evento contava com estrutura de brinquedoteca, uma estação de benzedeiras, onde houve uma concentração final e o evento foi encerrado.

O último caso analisado foi o protesto Justiça por Mari Ferrer que não contou com marcha, e sim com a concentração na Praça dos Três Poderes, tendo como alvo principal o prédio do Supremo Tribunal Federal (STF). O evento fez parte de uma onda de protestos ocorridos em diversas cidades e que estavam relacionados à indignação provocada pela divulgação de um trecho de uma audiência realizada via videoconferência na qual o réu acusado de estupro de vulnerável foi absolvido sob a alegação de que embora houvesse culpa, não havia dolo, ou seja, não houve intenção de cometer um crime e, para a qual a mídia e os movimentos sociais utilizaram o termo "estrupo culposo", um termo que não é previsto na justiça brasileira. Além disso, a humilhação e a culpabilização da vítima pelo estupro realizada pelo advogado de defesa foi o gatilho desses protestos. Das 
manifestações analisadas neste trabalho, este é o único que não fazia parte de uma agenda dos movimentos, pois surgiu em resposta a um acontecimento.

O material visual apresentado neste trabalho foi coletado por uma das autoras e por um colaborador fotógrafo durante a participação nos protestos, com o objetivo de registrar as diferentes visualidades fabricadas pelas mulheres ao participar do evento. Embora seja possível acompanhar as imagens por meio de publicações na mídia, sobretudo nas redes sociais, participar do ato permite o registro para além dos grupos organizados, sobretudo as pessoas autoconvocadas ${ }^{4}$, que costumam fabricar visualidades distintas. Observamos que os grupos organizados fabricam coletivamente suas visualidades: combinam a cor da roupa que utilizarão, vestem as mesmas camisetas, fabricam cartazes antecipadamente ou mesmo durante a concentração, para que sejam portados pelas integrantes do grupo no evento (Figura 1), elaboram material gráfico para distribuir ao público, como adesivos e panfletos. Na organização coletiva há espaço para a expressão individual, mas percebemos que o uso de imagens que demonstre ser parte de um coletivo é um fator preponderante, o que Charles Tilly (2009) chama de demonstrações concertadas de VUNC (valor, unidade, número e comprometimento), termo que se refere às lógicas compartilhadas por um determinado número de pessoas e que as distingue enquanto um movimento social. Já as pessoas que não fazem parte de grupos e movimentos costumam levar elementos visuais elaborados individualmente ou com um grupo pequeno de forma independente, que se distinguem das outras visualidades pela unicidade.

\footnotetext{
${ }^{4}$ Autoconvocadas são as manifestantes que vão ao protesto ou marcha e que não fazem parte de um movimento social organizado.
} 


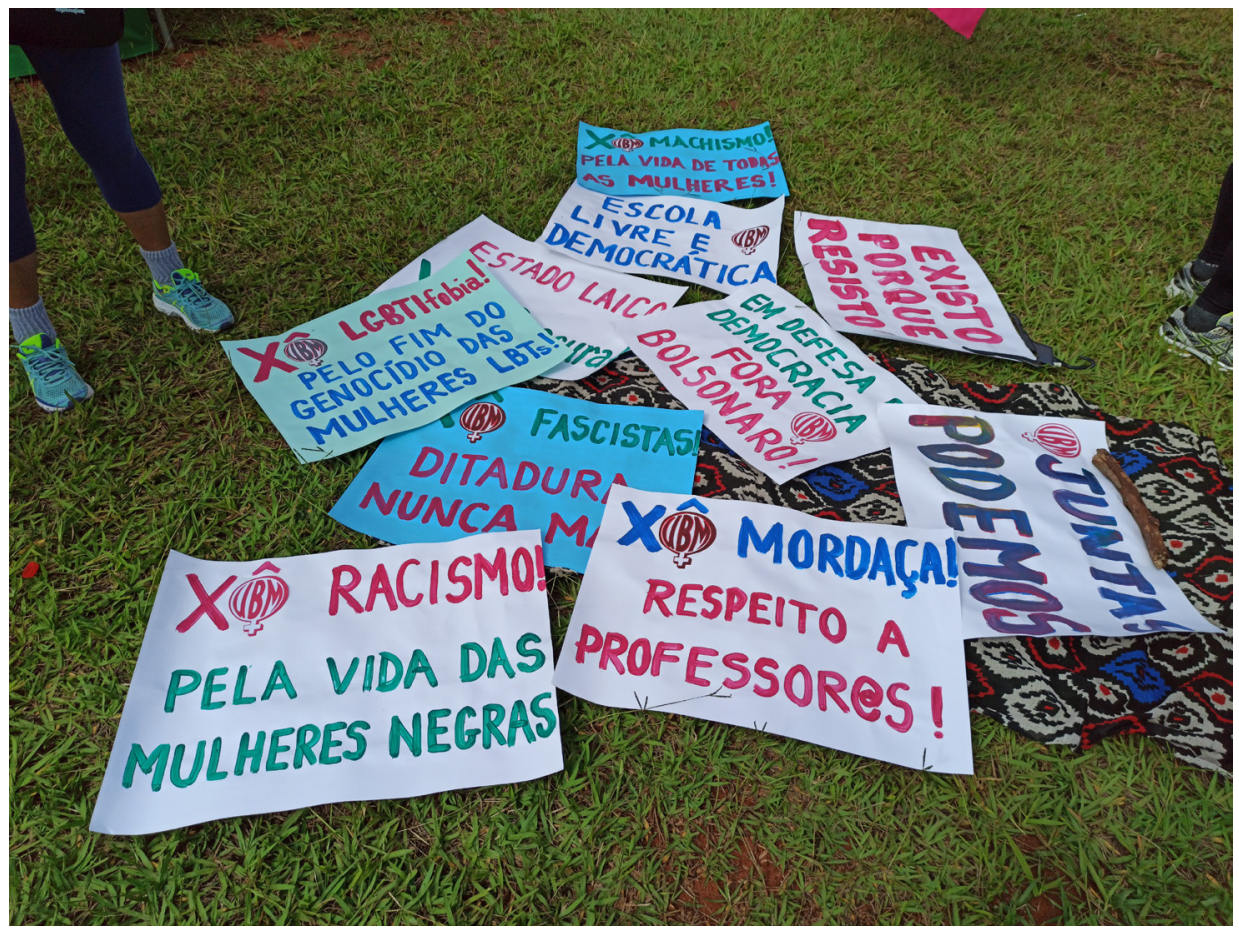

Figura 1. 8M 2020. Cartazes elaborados pela UBM (União Brasileira de Mulheres) dispostos no chão durante a concentração do evento. Fonte: Luciana Ceschin

Acompanhar a passagem de uma marcha ou estar em meio a um protesto é uma atividade carregada de estímulos visuais. Normalmente nos aproximamos das pessoas, pedimos autorização para fotografá-la, o que em todas as situações recebemos um olhar, um aceno de cabeça ou uma vocalização positiva, por vezes acompanhada de uma pose para a fotografia. É comum que as pessoas, ao perceber a intenção da fotografia, posem para o registro, erguendo cartazes, abrindo bandeiras, exibindo as visualidades preparadas para o evento. Compreendemos que as nossas reações aos estímulos visuais de uma manifestação estão condicionadas por práticas de olhar configuradas a partir de nossa prática cultural, de nosso repertório, forjados sobre uma estrutura construída a partir de nossas rotinas, da qual não conseguimos nos esquivar. Temos consciência de que ao fotografar em meio à multidão, diante da impossibilidade de documentar a totalidade do evento, fazemos seleções de quais pessoas e visualidades registraríamos e que estas seleções estão relacionadas com nossas referências e intenções, nem sempre conscientes no momento da elaboração da imagem.

Não raro, após o protesto, percebemos que o material disponibilizado nas redes sociais dos grupos ou na mídia apresentava muita semelhança com nosso material visual. As visualidades mais potentes, as que se destacam em meios às outras, são as que costumam ser veiculadas na mídia e que também se destacam em nossos registros, talvez 
por se distinguirem das visualidades já estabelecidas em protestos em geral e também nos protagonizados por mulheres (e.g. cartazes, camisetas, a predominância da cor roxa). No entanto, por vezes, ao acompanhar as imagens do protesto ou marcha na mídia, verificamos que alguns elementos não foram percebidos ou, talvez, não tenham sido alcançados pelo nosso olhar.

A partir dessas fotografias as autoras estabeleceram relações entre as imagens e elencaram categorias, como uma forma de processar esses registros para posteriormente interpretá-las. Não temos a intenção de sugerir que todos esses eventos são iguais e que as imagens representam a totalidade das visualidades, mas entendemos que elas não estão desconectadas a ponto de não permitir que se estabeleça ligações entre elas, encontre similaridades, recorrências e, a partir disto, permitam algumas generalizações e ponderações. Dentre as várias fotografias realizadas em cada evento, em meio às várias camadas de informação, selecionamos, para este trabalho, aquelas que registram as visualidades que se repetiam, identificando padrões e recorrências formais, estéticas ou temáticas.

Além das visualidades clássicas que fazem parte do repertório dos protestos em geral como cartazes e faixas, foi possível identificar objetos (e.g. lanças, vassouras, estandartes, instrumentos musicais, perna-de-pau), indumentária e acessórios (e.g. camisetas, lenços, roupas temáticas), tatuagem, pintura corporal e performance. Segundo Tilly (2006) os repertórios clássicos fazem parte da tradição ou memória política, mas são renovados e atualizados a partir de interações dos atores em outros campos e grupos. As inovações que entram para o repertório são aquelas que são mais eficientes e vantajosas, mas também aquelas que os grupos se identificam. Os repertórios são aproveitados por outros movimentos também pelo fato de permitir utilizar os ganhos políticos e simbólicos de outros grupos ou países, tornando mais fácil o seu entendimento. Jasper (2016), concordando com Tilly, afirma que em um protesto, o repertório utilizado normalmente está baseado em táticas comuns, que são clássicas para estes eventos, pois são entendidas de forma rápida pelos participantes e pelo público externo. No entanto, afirma que há várias determinantes culturais que influenciam os repertórios, como, por exemplo, experiência de indivíduos em outros movimentos e a interação com outros atores.

Butler (2018) afirma que um corpo, só de estar em um espaço público, já significa. No entanto afirma que "se aparecemos, devemos ser vistos, o que significa que nosso corpo deve ser enxergado, e seu som vocalizado deve ser ouvido: o corpo deve entrar no 
campo visual e audível" (Butler, 2018: 89). As tipologias de visualidades identificadas nos eventos analisados possuem em comum o fato de estarem inscritas no corpo, sobre o corpo ou suportadas pelo corpo de quem protesta. A partir de uma composição visual inscrita sobre si mesmo, o corpo se faz imagem e instrumento de comunicação, ampliando seus significados, sua visibilidade no meio da multidão e, também, provocando afetos.

\section{Estéticas dos protestos e marchas}

Ao seguirmos os protestos e marchas e ao organizarmos nossos entendimentos a partir das visualidades produzidas em manifestações tentamos buscar um caminho no qual a estéticas dos gestos, das visualidades e dos modos de se insurgir nos trazem pistas para pensar sobre trocas simbólicas entre diferentes comunidades, as funções que estas conferem ao visual, suas referências, quais discursos assumem, e quais são as suas alianças.

As classificações das estéticas destes protestos e marchas foram realizadas na tentativa de se conseguir realizar uma observação mais sistemática, pois entendemos que as visualidades descritas e analisadas, isoladas e ao mesmo tempo conectadas dentro de um sistema, mostram elementos do cotidiano dos protestos e nos conectam com uma história maior, produzindo relatos do mundo social.

Estudos sobre protestos são numerosos no Brasil e no mundo, mas raros os que se dedicam à dimensão estética desses eventos. Luciana Bertolaccini (2020) realizou pesquisa a respeito das estéticas dos protestos pró-aborto na cidade de Rosário, na Argentina, que faziam parte do que ficou conhecido como "Marea Verde", um conjunto de ações políticas realizadas ao longo dos últimos anos na reivindicação da legalização do aborto no país, que alcançou êxito no início deste ano. Em sua pesquisa, a autora identificou três estéticas recorrentes: a) a estética de luto ou dor, que seriam aquelas que estão relacionadas às vítimas de violência de gênero e tem o feminicídio como elemento central; b) a estética da guerreira, que seriam aquelas em que se exalta a capacidade de ação política de forma combativa; e c) a estética da diversão e do prazer, nas quais a autora inclui aquelas ações em que há dança, música, e que possuem caráter festivo.

Nos protestos analisados nesse trabalho, encontramos algumas correspondências entre as estéticas identificadas por Bertolaccini em sua pesquisa realizada em Rosário como as que se referem à violência, à ação combativa e à diversão e ao prazer. Adaptando a tipologia proposta pela autora e a partir de nossos registros, classificamos as estéticas 
como: (1) estética da violência e morte, (2) estética do empoderamento, (3) estética festiva, (4) estética da provocação, e (5) estéticas identitárias.

\section{Estética da violência e morte}

Uma mulher sentada, vendada. Usa um vestido branco que, como seu corpo, está coberto por tinta vermelha ou algo semelhante para representar sangue (Figura 2). Em suas mãos, um recipiente de cerâmica, cheio de sementes de girassol, alpiste ou painço, nas quais o "sangue" também escorre (Figura 3). Ela está sozinha e permanece imóvel nessa posição. Sua venda não permite acompanhar visualmente o que está acontecendo ao redor. Por que ela não está acompanhando a multidão? Além de violência, algo de vulnerável e solitário evoca de sua performance.

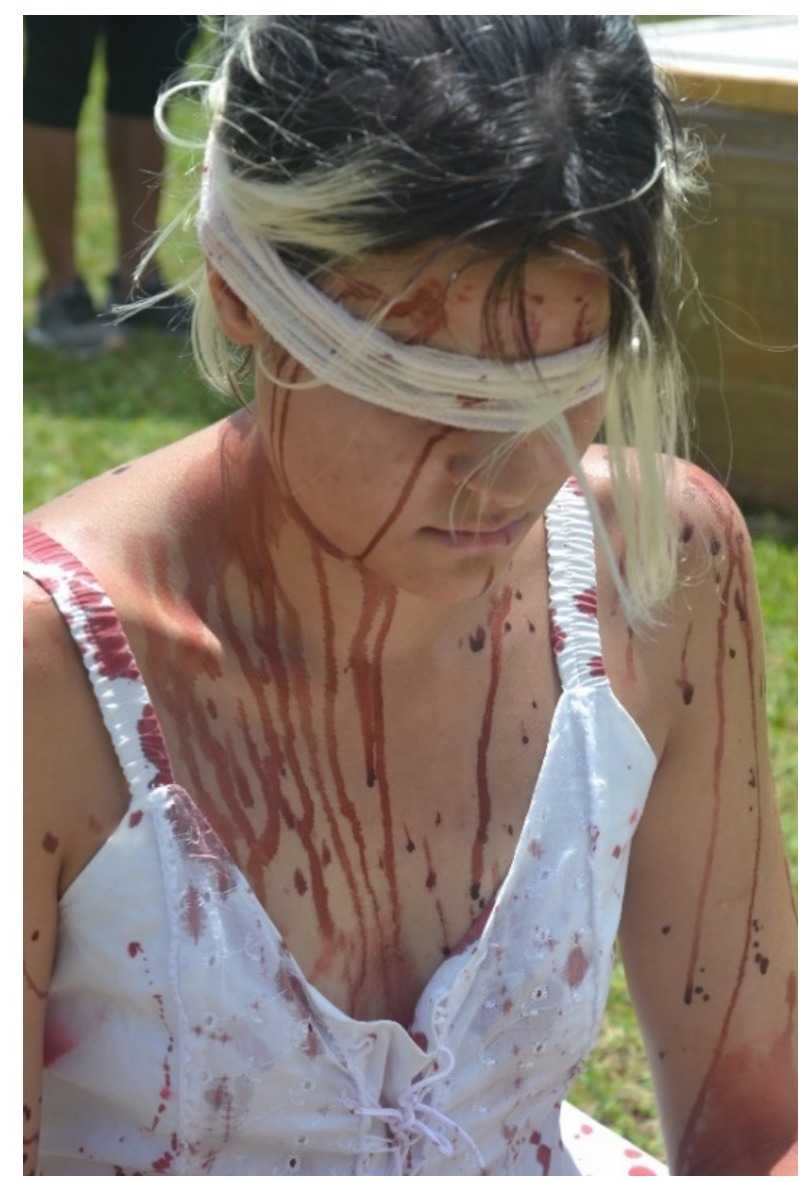

Figura 2. 8M 2020. Fonte: Ramon Gusso 


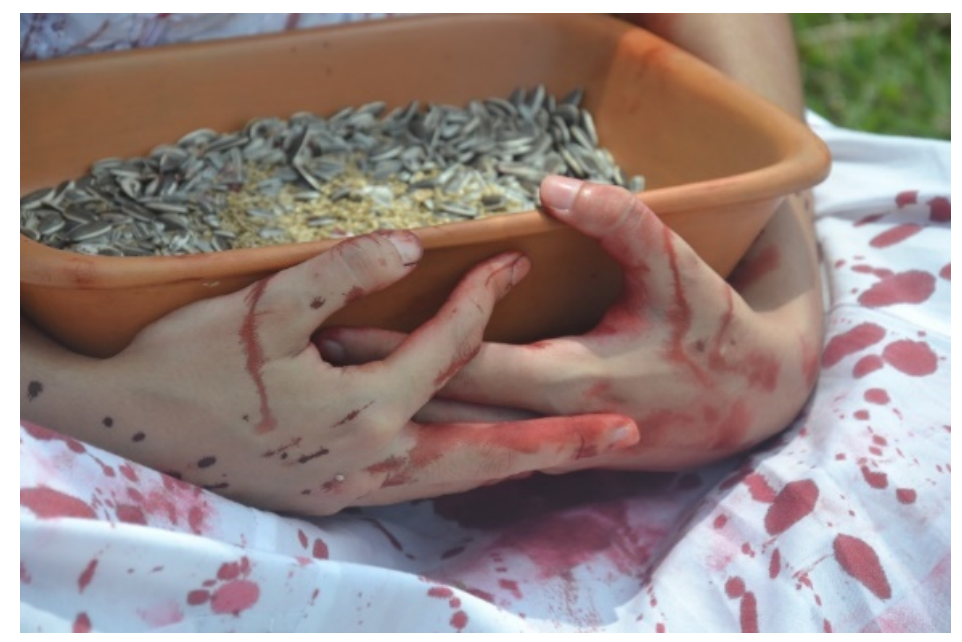

Figura 3. 8M 2020. Fonte: Ramon Gusso

Uma mulher com uma tira de pano preta tampando sua boca, como uma mordaça, na qual está escrita a palavra "machismo" em preto, sobre um papel de fundo amarelo (Figura 4). Veste uma camisa com marcas vermelhas feita com alguma tinta que lembra sangue. Em seu rosto e corpo, uma maquiagem em cores vermelha e roxo, que busca representar marcas de violência. Em suas mãos um cartaz, com os dizeres "a democracia é uma mulher que o Bolsonaro violenta todos os dias. Ele não. \#8M”. Ela posa para a foto, sua expressão é de seriedade.

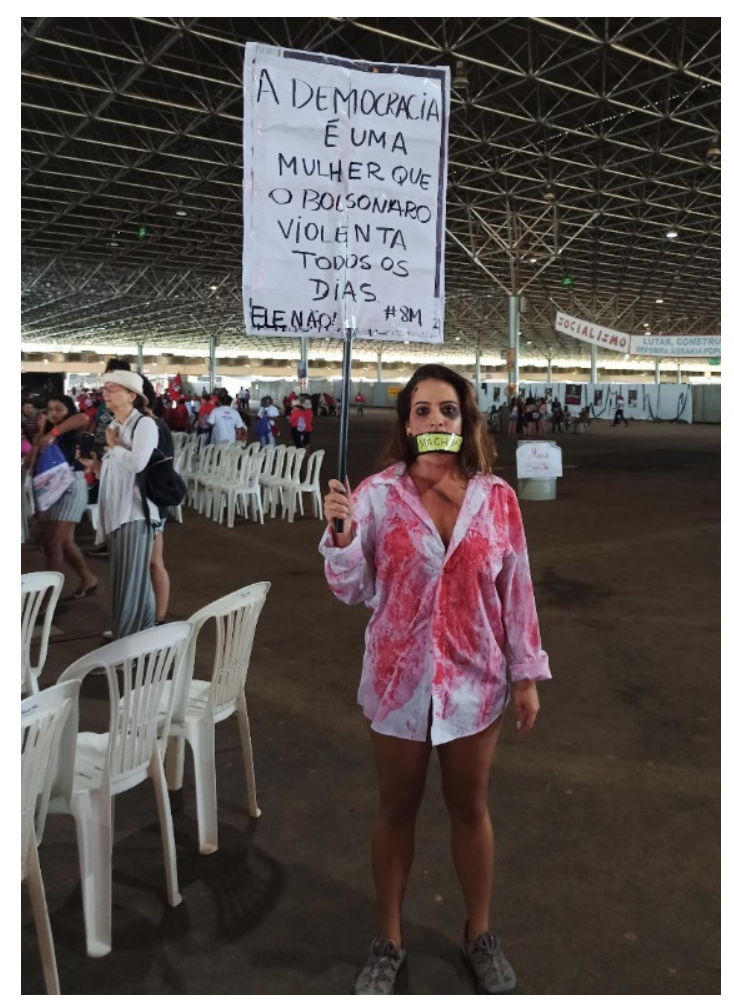

Figura 4. 8M 2020. Fonte: Luciana Ceschin 
No 8M de 2020, em determinado momento, a marcha parou em frente ao Palácio Buriti, sede do governo do Distrito Federal, e um ato começou a se organizar. Cartazes com nomes de mulheres que viviam na região, todas vítimas de feminicídio no ano anterior, são distribuídos entre as participantes (Figura 5). Os nomes foram lidos e ouve um discurso acompanhado de silêncio, momento em que foi possível perceber muitas participantes emocionadas.

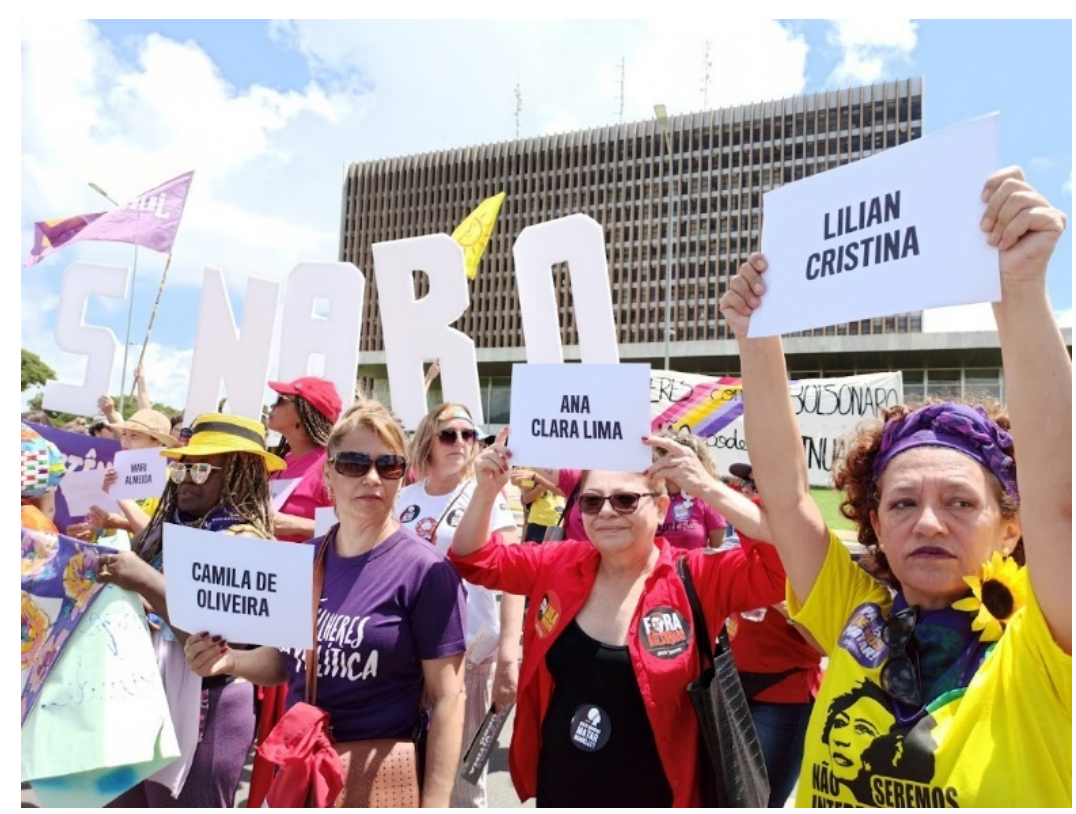

Figura 5. 8M 2020. Fonte: Luciana Ceschin

Uma mulher vestindo roupas e uma máscara preta, segurando um cartaz de papel amarelo com inscrições como plano de fundo, em preto, com frases retiradas da fala do advogado de defesa, dirigidas à Mari Ferrer, durante a audiência "peço a Deus que meu filho não encontre uma mulher como você. Seu ganha pão é a desgraça dos outros. Lágrimas de crocodilo". Sobre este fundo, uma frase em tinta vermelha diz "eu tô implorando por respeito". No centro do cartaz, o desenho de uma face com traços em tinta preta. Lágrimas vermelhas saem dos olhos da mulher no desenho, além de um ' $X$ " vermelho, tampando a sua boca. Ao lado desta mulher, um homem segura um cartaz em papel preto com a frase em tinta branca "um estuprador é um filho saudável do patriarcado. \#justiçapormariferrer " (Figura 6).

Segundo Jaspers (2016) estabelecer vítimas é um dos elementos centrais para um movimento social, pois é o que torna visível um problema ou crime, é o que demonstra 
que um dano precisa ser corrigido. A partir do momento que se identifique a vítima, é preciso, também, designar um vilão, pois se não encontrar alguém a quem culpar, o que as vítimas vão provocar é compaixão, e não indignação. Ler os nomes das vítimas do feminicídio em frente ao Palácio Buriti e rememorar a violência sofrida por Mari Ferrer em frente ao STF é uma forma de identificar o Estado como vilão, um agente importante na reprodução da violência contra a mulher.

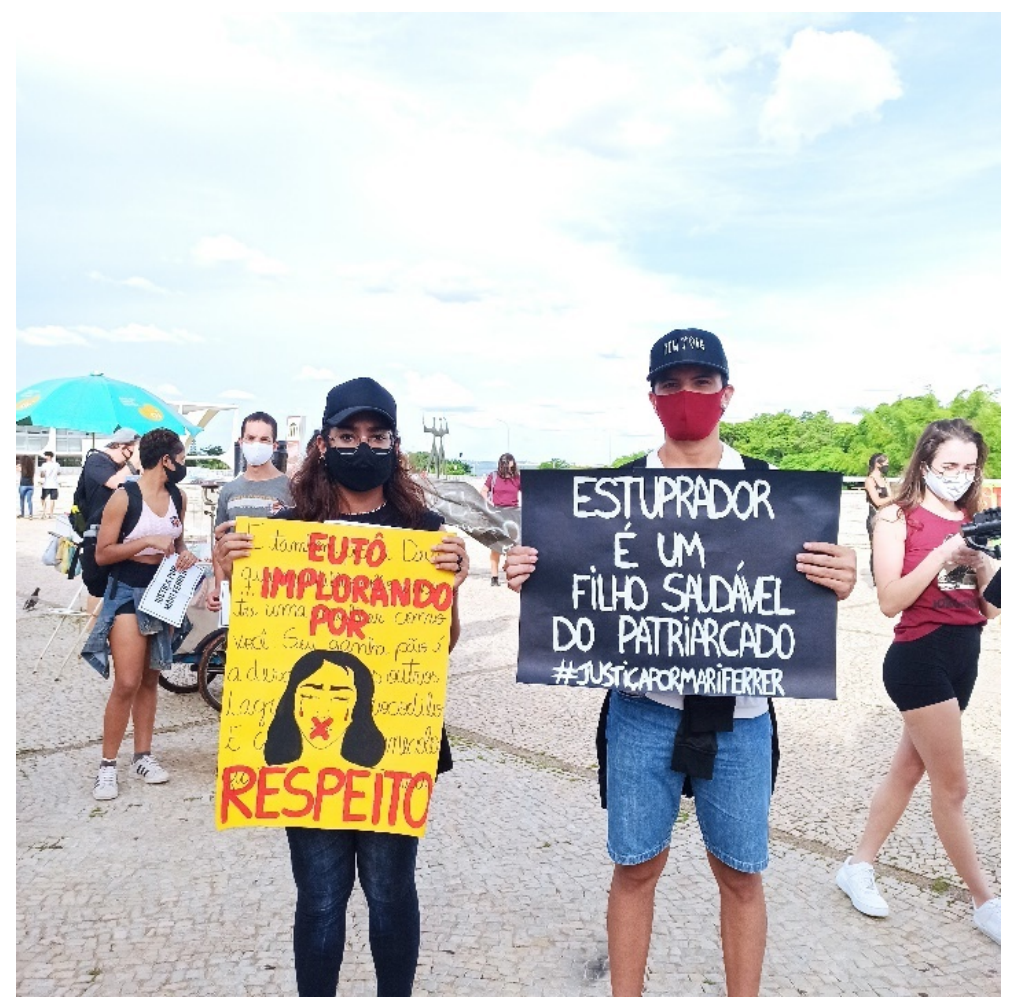

Figura 6. Justiça por Mari Ferrer. Fonte: Luciana Ceschin

Uma mulher parada, assistindo a passagem da marcha, segurando um artefato composto por um fundo com notícias recortadas de jornais, uma cabeça de boneca para treino, das que se usa em escolas de cabelereiros, para a qual uma grande réplica de arma está apontando para a testa, com uma etiqueta que diz "Quando você cala, você também puxa esse gatilho" (Figura 7). Ela estava sozinha, aparentemente não fazia parte de um grupo ou coletivo. A visualidade que trouxe para participar da marcha aparenta ser resultado de um trabalho elaborado, que imaginamos que tenha demandado tempo na seleção de cada elemento e na montagem da peça, que chama a atenção para a importância de denunciar casos de violência doméstica e contra a mulher. 


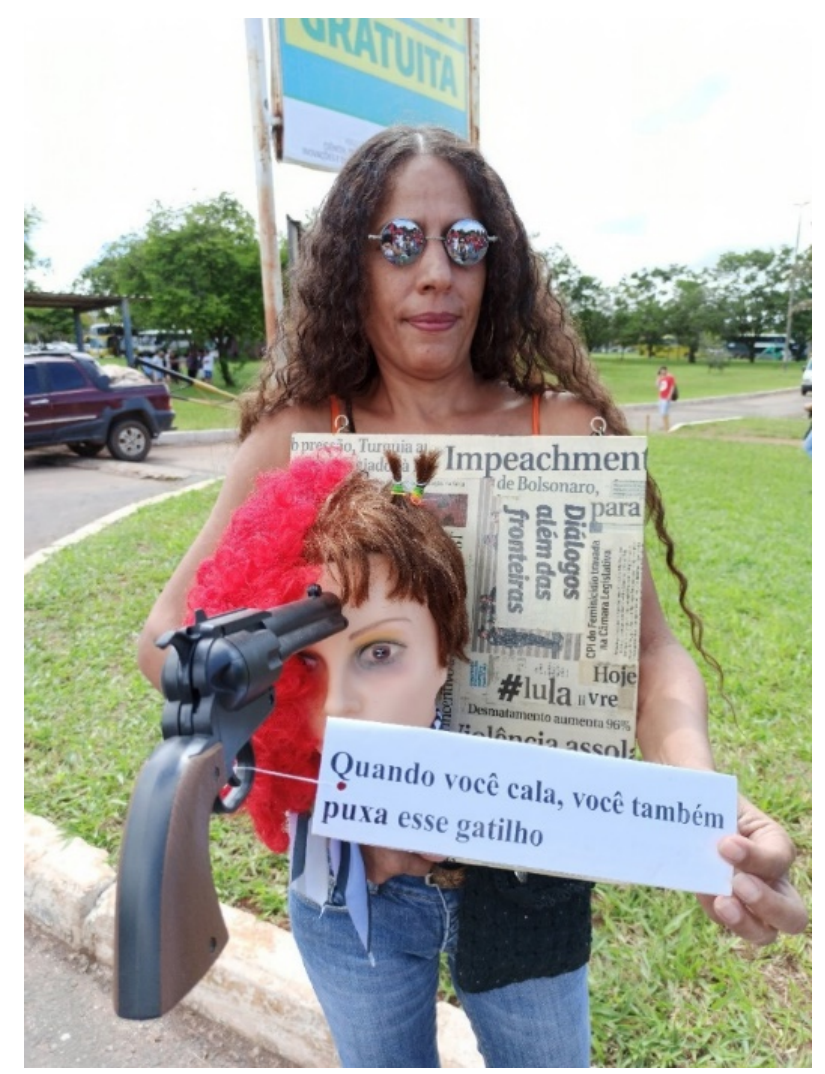

Figura 7. 8M 2020. Fonte: Luciana Ceschin

A mordaça, instrumento que impede de falar, a venda, instrumento que não permite reconhecer onde se está, são objetos que simbolizam o controle sobre o corpo e são imagens que aparecem diversas vezes nos eventos analisados. A representação do sangue em tinta vermelha em cartazes, performances e indumentárias também é um elemento recorrente. A artista cubana estado-unidense Ana Mendieta (1948-1985) que, inclusive morreu sob circunstâncias incertas, das quais há rumores de que tenha sido vítima de feminicídio, em suas obras como, People Looking at Blood, de 1973 e Untitled (Blood Sign \#2/Body Tracks), de 1974 utiliza o sangue animal em performances que realizou em casa, provocando a ideia da violência que ocorre em espaços domésticos. Sobre o uso das representações que remetem ao sangue em protestos sobre a violência do Estado no México e na arte contemporânea latino-americana, Dieguez Caballero, afirma que os discursos e práticas artísticas demonstram um transbordamento sensorial entre cenas reais de violência que fazem emergir dos vestígios das atrocidades. O vermelho sangue, tanto na arte como nos protestos, são como "A mimese do sangue como mimese dos corpos que nos faltam. Uma encarnação vermelha e espectral da ausência " (Dieguez Caballero, 2018: 208, Tradução das autoras). 
As imagens demonstram construções visuais que representam as diferentes formas de violência que vitimizam mulheres todos os dias, como por exemplo, a violência doméstica, o estupro e o feminicídio. As visualidades identificadas são formas de visibilizar essas perdas, a partir de ações de memória que dramatizam e ritualizam essas violências.

\section{Estética do empoderamento}

Circulou, no $8 \mathrm{M}$, tatuagens temporárias que eram aplicadas na concentração que antecedeu a marcha. São tatuagens com frases que dizem, por exemplo, "não é não" "Respeita as minas". Essas tatuagens são realizadas pela Conspiração Libertina e costumam circular também durante o Carnaval em Brasília. A marca é especializada em comercializar peças com design ativistas, como cartazes, adesivos, ímãs, bandeiras. Uma mulher aplicava a tatuagem, com o auxílio de uma garrafa de água, necessária para a transferência da imagem para a pele, em quem se aproximasse e pedisse, até que esgotasse o material. Em nosso registro (Figura 8), uma dessas imagens diz "Elas no poder", acompanhada de diferentes silhuetas de mulheres. Essa tatuagem foi produzida em parceria com a ONG \#ElasNoPoder que atua apoiando candidaturas de mulheres.

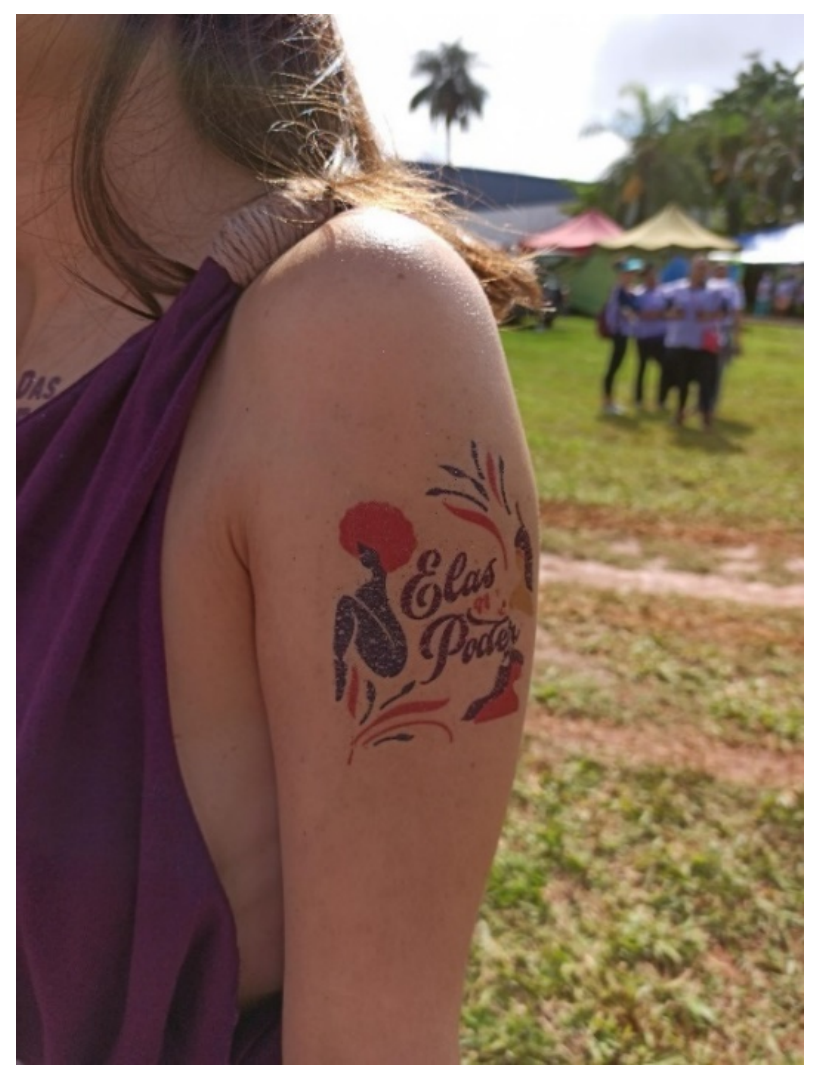

Figura 8. 8M 2020. Fonte: Luciana Ceschin. 
Uma mulher segura um cartaz composto por imagens de mulheres empunhando facões, foices, arco e flecha (Figura 9). As imagens representam mulheres em posição de luta, com elementos que remetem à mulher do campo, do movimento dos trabalhadores rurais sem terra e à mulher indígena. Suas armas são as suas ferramentas.

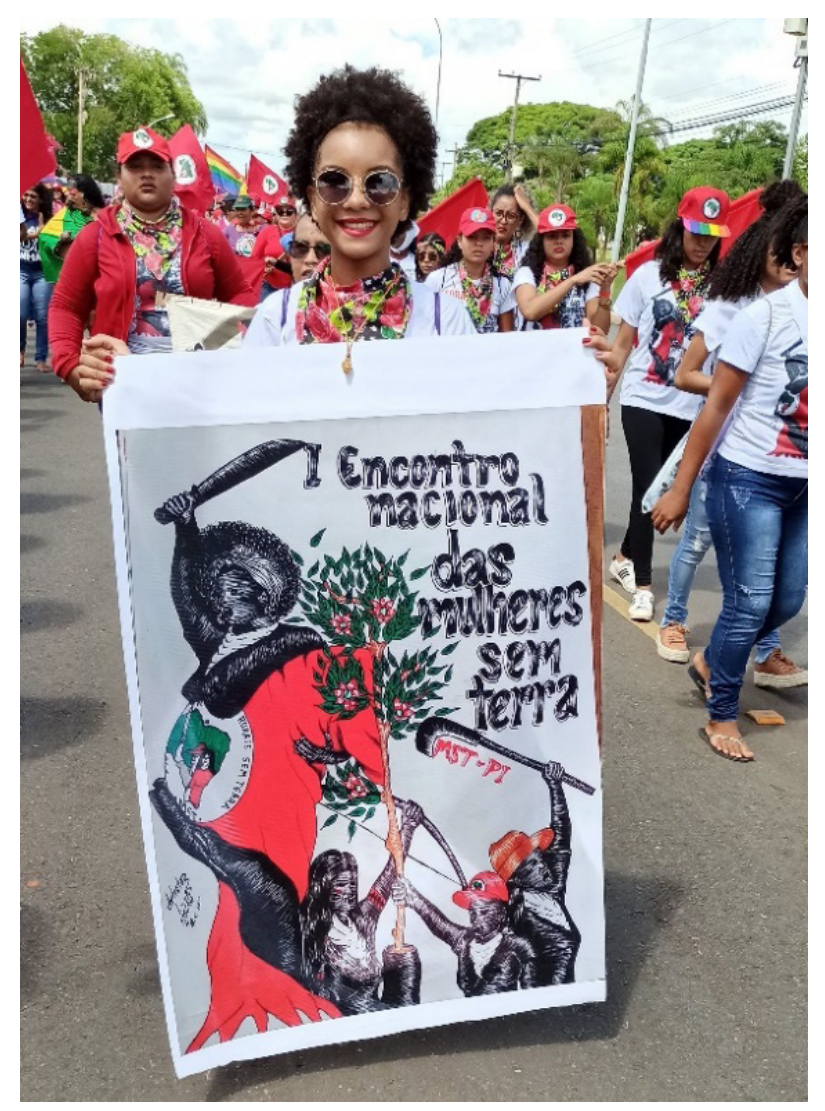

Figura 9. Marcha das mulheres sem terra/8M 2020. Fonte: Luciana Ceschin

Segundo Jaspers (2016:220), os “movimentos sociais são um grande laboratório para compreender como as pessoas se reúnem para colaborar, voluntariamente, para um propósito comum”. A essência da vida social, para o autor, é a ação coletiva, na qual a confiança e união a outras pessoas permite que se indigne e que seja possível reagir às ameaças aos direitos. As visualidades relacionadas à esta estética, recorrem a elementos que buscam simbolizar a união das mulheres e que esta aliança é uma forma de enfrentamento.

\section{Estética festiva}


No 8M algumas bandas e grupos musicais, integradas exclusivamente por mulheres, tocaram e participaram da marcha, dando ares de festa ao evento. $\mathrm{O}$ grupo Batalá Brasília (Figura 10), que é de percussão; o Baque Mulher, que é de maracatu; e o Malu Vidas, que é uma fanfarra. Todos esses grupos também marcam presença em blocos de carnaval em Brasília.

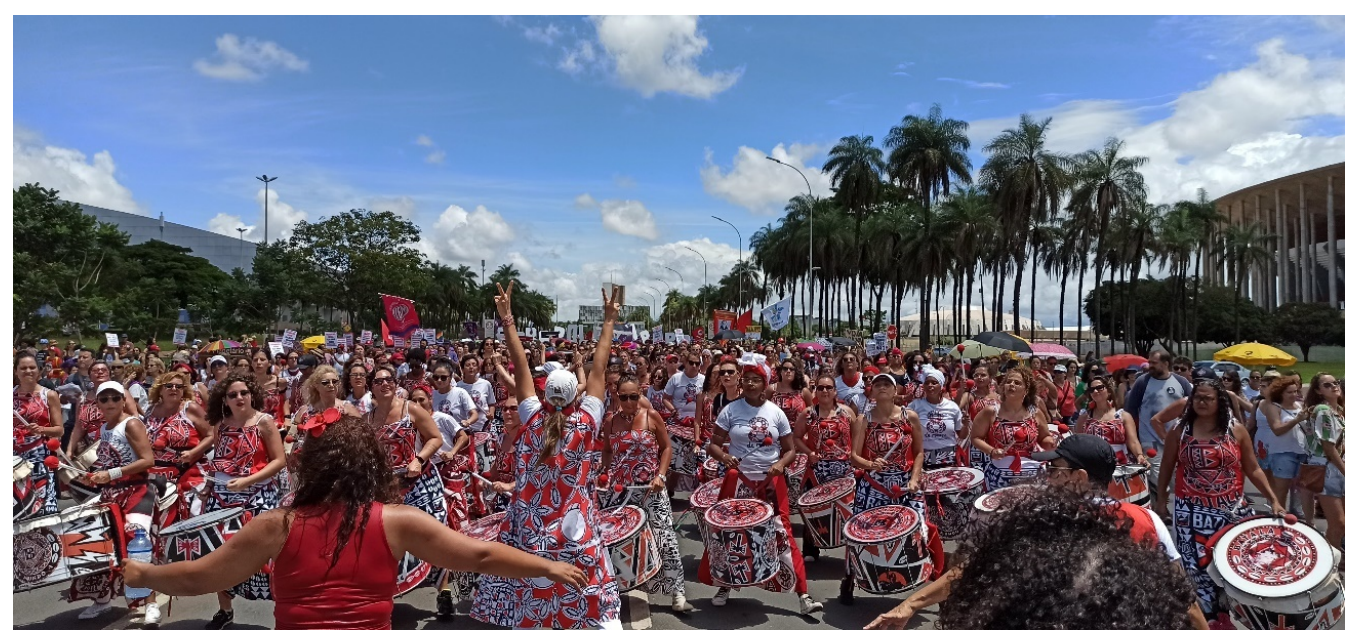

Figura 10. 8M 2020. Fonte: Ramon Gusso

Também acompanhou a marcha um grupo de mulheres "pernaltas" (Figura 11), uma modalidade circense em que se utiliza um artefato conhecido como perna de pau para modificar a estrutura do corpo. Em alguns momentos elas pararam e seguravam uma faixa que dizia "Juntas somos gigantes".

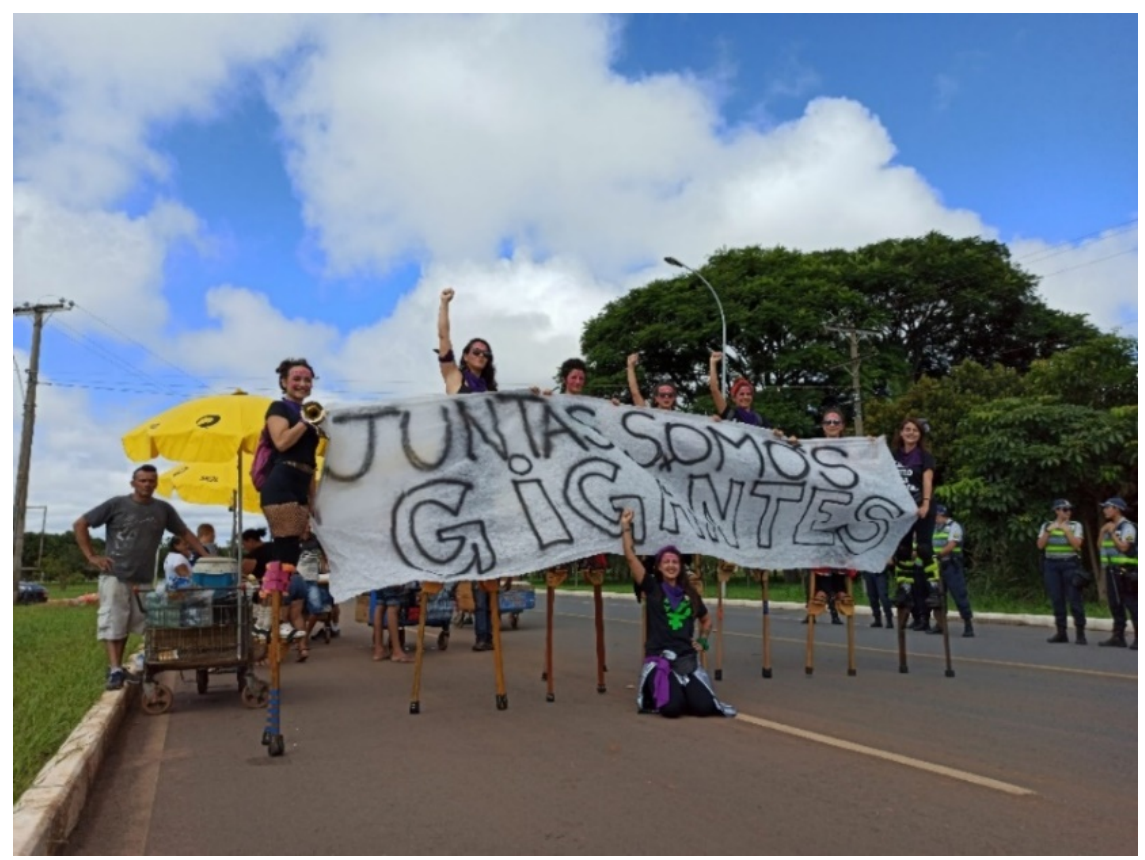


Figura 11: 8M 2020. Fonte: Luciana Ceschin

Jaspers (2016) afirma que protestos podem ser eventos divertidos. Ações como marchar, cantar e gritar coletivamente são estimulantes, mesmo quando essas ações são acompanhadas de riscos. Segundo o autor,

A simples proximidade de outras pessoas desencadeia vários processos de sentir-pensar. O resultado é um pico de energia emocional que associamos ao encontro, ao grupo que o organizou e à causa pela qual estamos lutando. Estamos bem-dispostos, sensação que persiste por dias ou semanas após o fim dos eventos. Quando estes vão bem, gerando esta energia, os participantes passam a ansiar por eles. Voltarão. (Jasper, 2016: 136, 137)

Do momento de luto, em frente ao Palácio Buriti, no qual as vítimas de feminicídio foram lembradas, o $8 \mathrm{M}$ também foi marcado por performances em que a dança e a musicalidade abriram frestas no espaço da rua, com ares de Carnaval, para que ela também seja espaço de festa entre mulheres. O entusiasmo compartilhado também comprova solidariedade entre as participantes do evento.

\section{Estética da provocação}

Mulheres fazendo topless, vestindo lingerie, meias arrastão, também foram identificadas na marcha do 8M (Figura 12). A estética da provocação vem sendo utilizada em protestos na sociedade brasileira, sobretudo os feministas, desde que ocorreram, em 2011, as SlutWalks, um movimento que teve início no Canadá. A primeira SlutWalk ocorreu como uma resposta a fala de um policial em um evento sobre segurança na Universidade de Toronto na qual afirmou que "as mulheres deviam evitar se vestir como vadias (sluts)", justificando que a violência sexual ocorre de acordo com o comportamento das mulheres sobre seus próprios corpos, ou seja, elas são culpadas pela violência que sofrem. As marchas do movimento chamam a atenção para a cultura do estupro, a autodeterminação da mulher sobre seu corpo e sua presença no espaço público livre de medo. Esse movimento teve alcance mundial a partir das redes sociais e teve versões em vários países. No Brasil, o movimento assumiu o nome de Marcha das Vadias, com o slogan "Se ser livre é ser vadia, somos todas vadias". 


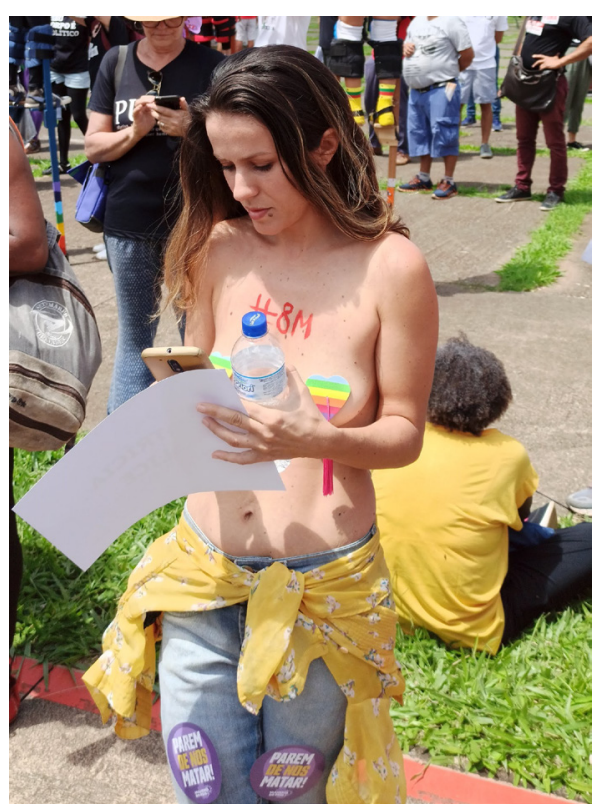

Figura 12: 8M 2020. Fonte: Luciana Ceschin

Segundo Gomes e Sorj (2014), a provocação como linguagem política na Marcha das Vadias tem o corpo como instrumento de comunicação no questionamento das regras e imposições sobre o corpo feminino no espaço público. A esse respeito, as autoras afirmam que, o corpo além de ser um objeto de reivindicação é também o principal instrumento de protesto e suporte de comunicação, sendo considerado um "corpobandeira". De acordo com as autoras:

Ao subverter o uso acusatório do termo "vadia", a marcha reivindica o termo para si e o ressignifica positivamente como "empoderamento". O slogan "Se ser livre é ser vadia, então somos todas vadias", comum às marchas de diversas cidades, ilustra esta ideia central. Para expressála, as/os participantes lançam mão de roupas sensuais, batom vermelho e topless nas marchas. Palavras de ordem são escritas em seus corpos, como "meu corpo, minhas regras", "meu corpo não é um convite", "puta livre", "útero laico", "sem padrão". (Gomes; Sorj, 2014: 437)

Colaborando com as ideias de Gomes e Sorj (2014), Guzzo e Wolf (2020) afirmam que as Marchas das Vadias contribuíram com novas formas de ser feministas que são apropriadas por outros movimentos, como nas Marchas do 8M. Apropriação das marchas das vadias por outros movimentos se relacionam com a estética, mas também com "uma política que envolve os corpos, os sentidos, as emoções e afetos e sua potência" (Guzzo e Wolf 2020: 10). A provocação, no entanto, pode ser entendida como uma herança de trabalhos de artistas das décadas de 1960 e 1970 que se engajavam em questões 
feministas, cujas obras demonstram o uso frequente do corpo nu como forma de reapropriação política e também do repertório do movimento LGTQIA+.

\section{Estéticas identitárias}

Um grupo de mulheres segurando lanças, todas vestindo saia vermelha, biquini e colares de contas (Figura 13). O corpo pintado com urucum e jenipapo. Marcham com passos ritmados, entoam canções numa das línguas indígenas.

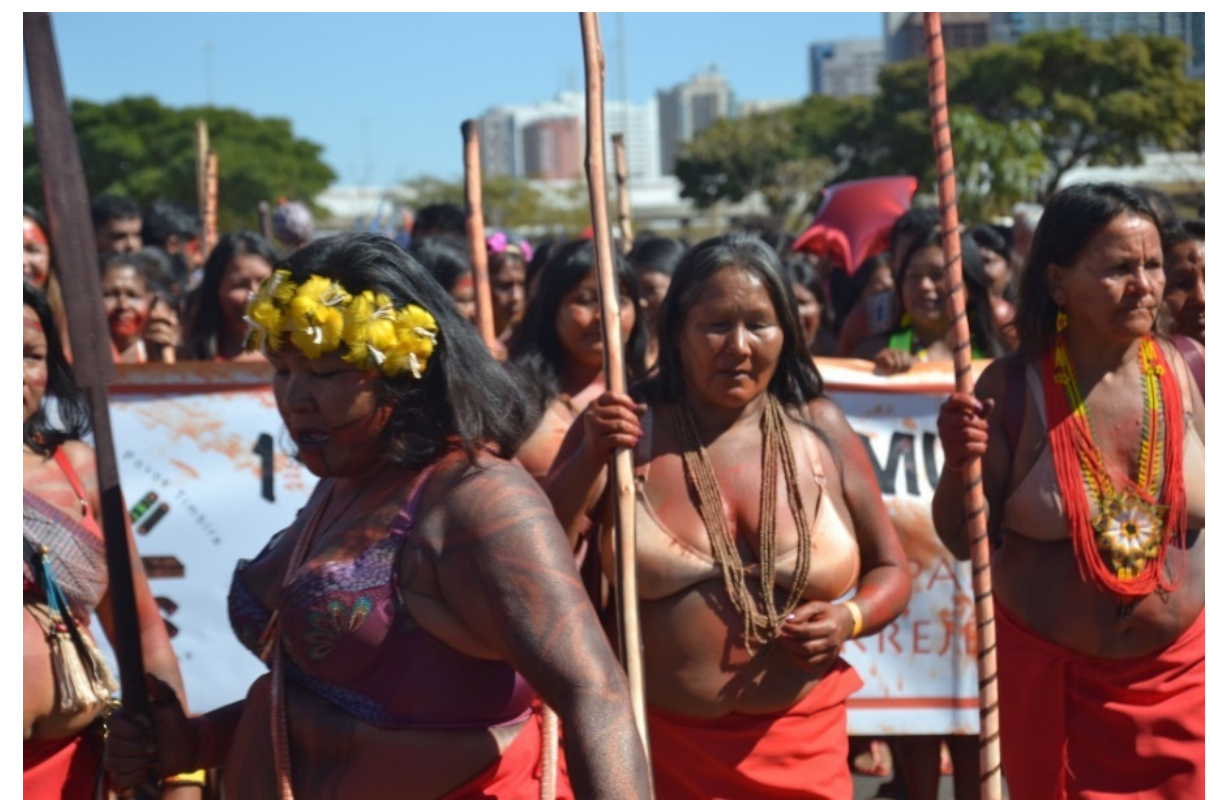

Figura 13. $1^{\text {a }}$ Marcha das Mulheres Indígenas. Fonte: Luciana Ceschin

Outro grupo de mulheres de braços dados, vestindo biquini preto, colares de contas coloridas, cocares de penas amarelas, pretas e vermelhas (Figura 14). Corpos pintados com jenipapo e urucum em cuidadosos e precisos grafismos. Caminhavam juntas, cantando em sua língua. 


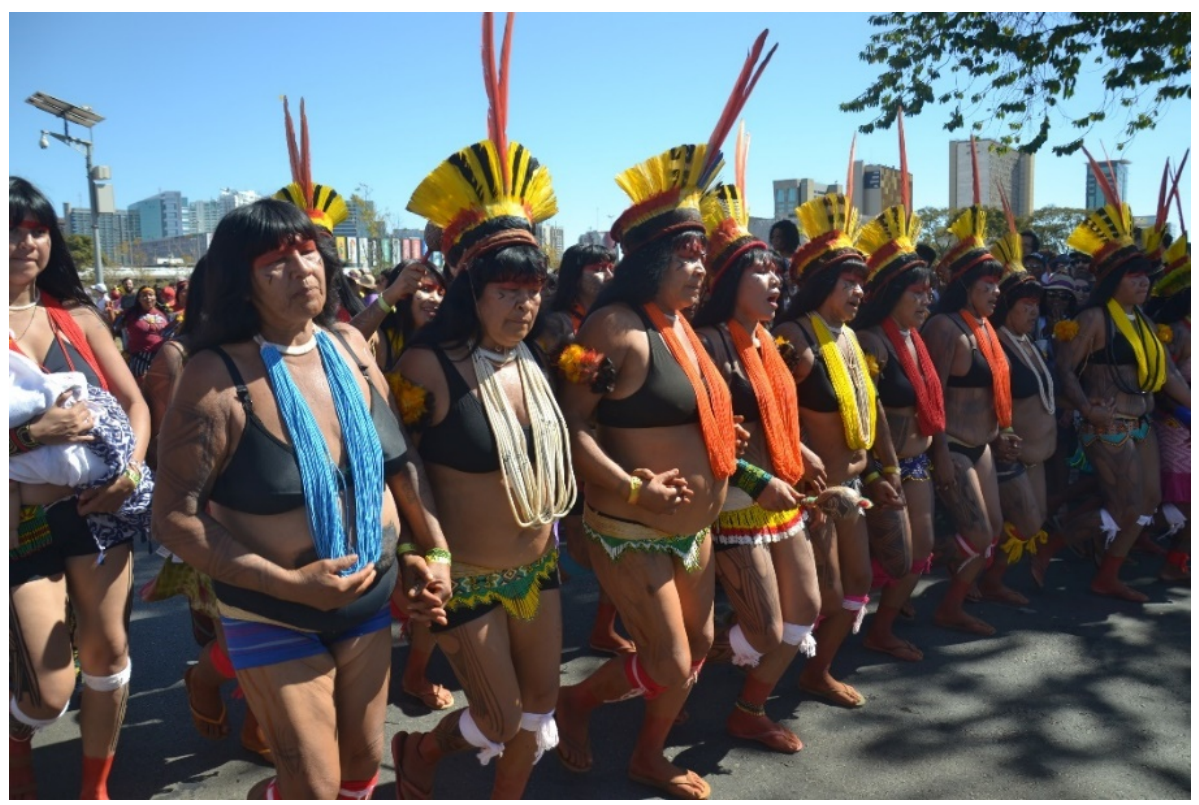

Figura 14. $1^{\text {a }}$ Marcha das Mulheres Indígenas. Fonte: Luciana Ceschin

Segundo o documento final da Marcha das Mulheres Indígenas, foram 2.500 mulheres de mais de 130 diferentes povos indígenas. São mulheres que viajaram muitos quilômetros, vindas de todas as regiões do país, para chegar em Brasília. São mulheres indígenas que ocupam os espaços simbólicos da capital do país com suas marcas identitárias que perpassam a indumentária, a pintura corporal, a língua, a música, a dança. Ao tornar visível suas identidades, reivindicam respeito pelos seus modos de vida.

Mulheres portando uma vassoura de piaçava em uma das mãos e, na outra, uma clava, com a qual batiam no cabo de vassoura, produzindo um som ritmado e orquestrado que acompanhava o cancioneiro (Figura 15). Muitas mulheres utilizando em suas cabeças chapéu de palha, o boné do Movimento dos Trabalhadores Rurais Sem Terra ou ainda, o lenço de chita. O lenço também foi utilizado pelas mulheres da marcha ora cobrindo o rosto, ora atado ao pescoço. 


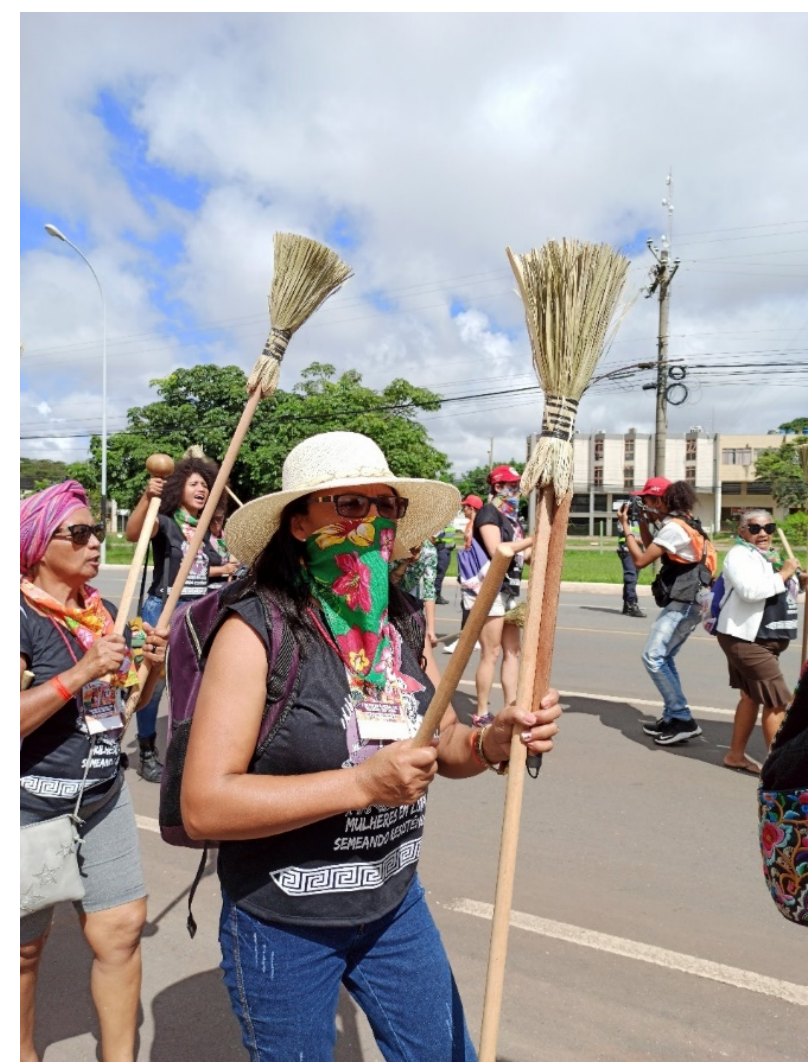

Figura 15. $1^{\text {a }}$ Marcha das Mulheres Sem Terra. Fonte: Luciana Ceschin

Uma mulher segura um estandarte feito em chita (Figura 16), com fitilhos de cetim coloridos, com a imagem da Irmã Dorothy Stang, religiosa que desenvolvia atividade pastoral e missionária relacionada aos trabalhadores rurais na Amazônia e que foi brutalmente assassinada em 2005. Outros estandartes semelhantes eram carregados por outras participantes, com imagens de mulheres que são referência para o movimento feminista e para o movimento campesino no Brasil, como Marielle Franco, Roseli Nunes, Margarida Alves, entre outras. 


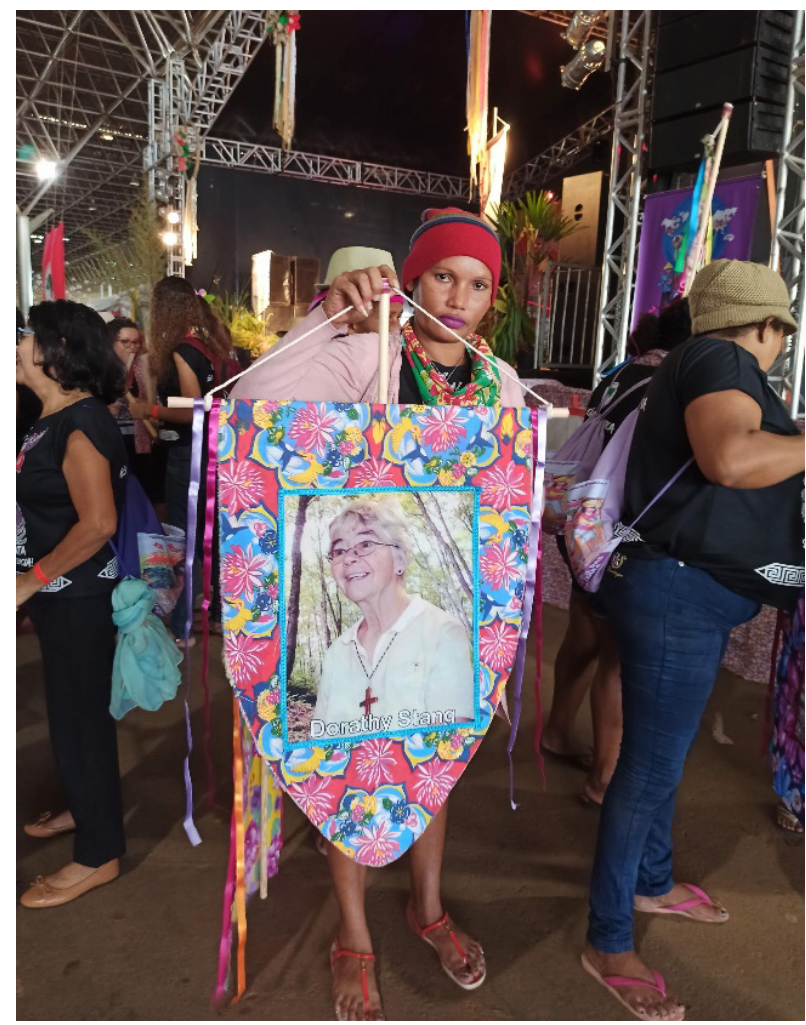

Figura 16. $1^{\mathrm{a}}$ Marcha das Mulheres Sem Terra. Fonte: Luciana Ceschin

Na Marcha das Mulheres Sem Terra, um elemento era compartilhado por todas as participantes: o lenço de chita (Figura 17). A presença do lenço marca visualmente vários protestos e marchas feministas na América Latina e sua origem está inscrita no movimento das Mães da Praça de Maio, na Argentina. Ressignificados na cor verde, recentemente foi o principal símbolo do movimento pró-aborto na Argentina, rapidamente disseminado em outros países da região. Como afirma Dieguez Caballero (2018:208, tradução das autoras) “Carregados nas cabeças das mães de luto argentinas, ou expostos como documentos e testemunhos de horror e perda, os lenços condensam as narrativas de dor na América Latina”. 


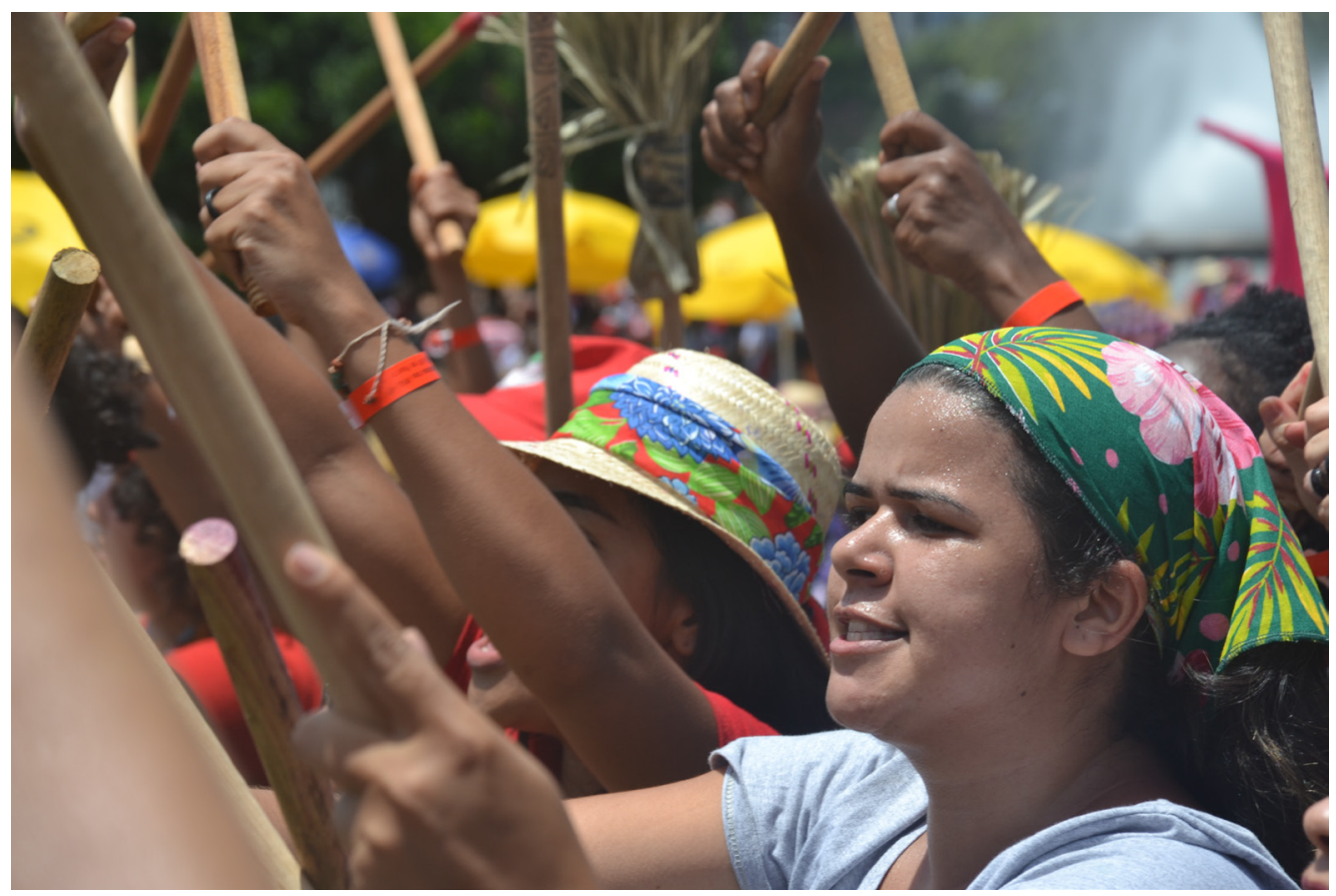

Figura 17. $1^{\mathrm{a}}$ Marcha das Mulheres Sem Terra. Fonte: Ramon Gusso.

O tecido de chita é originário da Índia, mas evoca ideias como tradição, simplicidade, feminilidade e brasilidade nos lenços, faixas e estandartes empunhados pelas das mulheres do MST e no 8M. O tecido é feito em algodão com estampa floral, geralmente em cores primárias em combinações entre quentes, frias e complementares. Talvez seja, historicamente, o tecido mais barato disponível no país, utilizado para encapar colchões, fazer cortinas, toalhas de mesa e para vestir as camadas mais pobres da população. É também muito utilizado em festas populares, como São João, Carnaval e Bumba-meu-boi. Personagens de obras importantes da literatura brasileira como Pombinha, do romance O Cortiço, de Aluísio Azevedo; e Capitu, de Dom Casmurro, de Machado de Assim, são descritas por seus autores vestindo chita. As duas obras narram mulheres que, em uma sociedade escravocrata e patriarcal, tensionam a ideia de casamento e de uma vida livre do domínio masculino.

Uma mulher posa para a foto exibindo um disco em vinil que está preso ao seu pescoço (Figura 18), como um colar, no qual, ao centro, está afixada a imagem e o nome de Maria Firmina dos Reis, professora, romancista abolicionista, a primeira mulher brasileira a publicar um romance. Ela usa turbante, um colar de búzios e em sua face uma pintura com pontos em cor branca, que remetem sua ancestralidade. O búzio é um 
elemento muito presente nas religiões de matriz africana, tanto as tradicionais como as da diáspora.

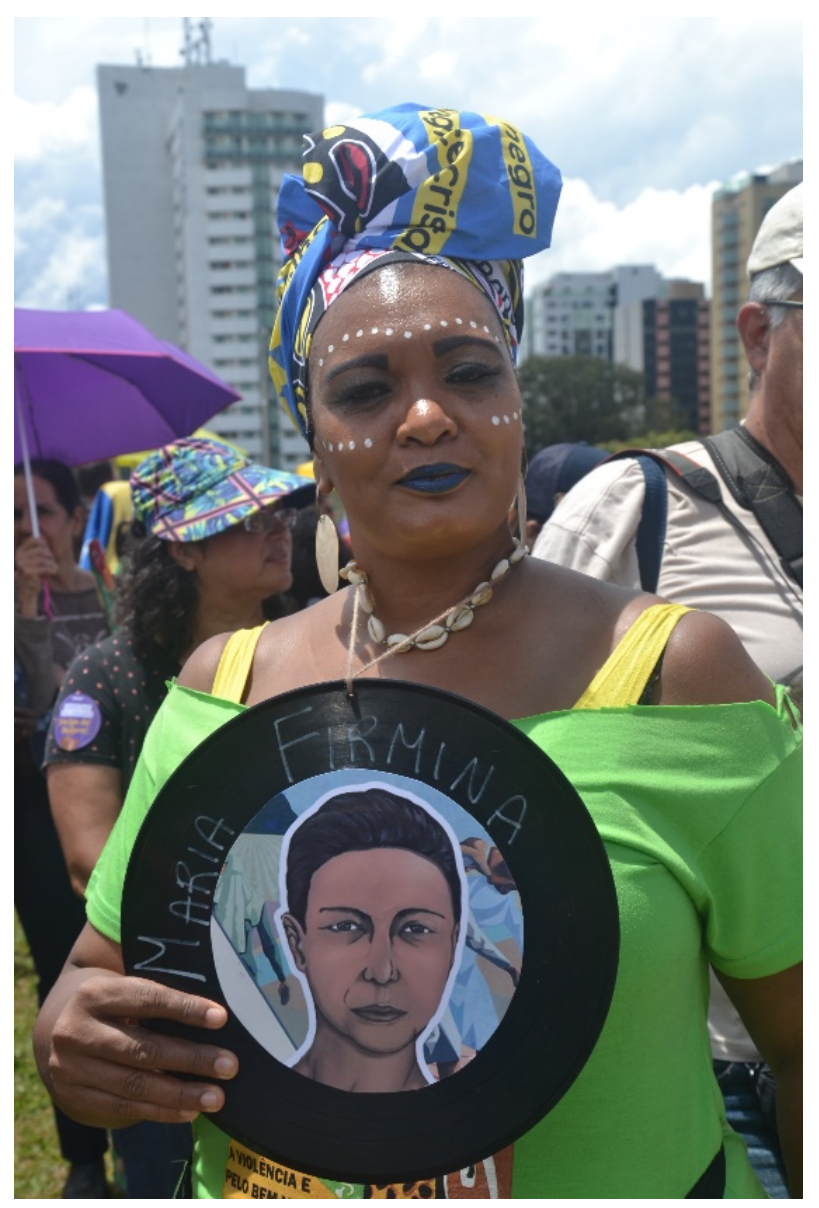

Figura 18. 8M 2020. Fonte: Ramon Gusso.

Mulheres indígenas, mulheres negras, mulheres do campo marchando na capital do país, por si só, já é algo repleto de significações. Propomos a categoria estéticas identitárias não com a intenção de afirmar que outros grupos não possuem identidade, ou mesmo de opor uma em relação à outra, mas enquanto categoria analítica da dimensão estética dos protestos protagonizado por mulheres, na qual grupos exaltam visualmente suas identidades de mulheres indígenas, de mulheres negras ou de mulheres do campo e fazem dessa visualidade um repertório de protesto. 
As visualidades que marcam suas identidades são também aquilo pelo que também se luta no espaço público, seus modos de vida, suas tradições. No documento final da Marcha das Mulheres Indígenas (2019), o movimento afirma que

\begin{abstract}
Enquanto mulheres, lideranças e guerreiras, geradoras e protetoras da vida, iremos nos posicionar e lutar contra as questões e as violações que afrontam nossos corpos, nossos espíritos, nossos territórios. Difundindo nossas sementes, nossos rituais, nossa língua, nós iremos garantir a nossa existência (...) não basta reconhecer nossas narrativas é preciso reconhecer nossas narradoras. Nossos corpos e nossos espíritos têm que estar presentes nos espaços de decisão (Documento final da Marcha das Mulheres Indígenas, 2019)
\end{abstract}

Para Butler (2018) quando corpos se unem em assembleia, além de representar sua existência plural no espaço público "eles também estão fazendo exigências mais abrangentes: estão reivindicando reconhecimento e valorização, estão exercitando o direito de aparecer, de exercitar a liberdade, e estão reivindicando uma vida que possa ser vivida" (Butler, 2018: 31).

\title{
Considerações finais
}

Os protestos e marchas nos apresentam visões de mundo e outros olhares para a realidade, buscam chamar a atenção das pessoas na tentativa de provocar experiências e gerar impactos, sejam individuais, coletivos ou nas instituições. As visualidades destes eventos são estímulos que trazem estranhamento, atraindo a nossa atenção para diferentes versões de como é possível viver no mundo, mesmo que com suas tensões e disputas.

Um protesto ou uma marcha é um acontecimento colaborativo. Rancière denomina como partilha do sensível "o sistema de evidências sensíveis que revela, ao mesmo tempo, a existência de um comum e dos recortes que nele definem lugares e partes respectivas" (Rancière, 2009: 15). Ao buscar mapear os repertórios visuais de protestos é possível pensar que fazemos, também, um "recorte sensível do comum da comunidade, das formas de sua visibilidade e de sua disposição" (Rancière, 2009: 26).

O repertório de visibilidades e as estéticas identificadas demonstram interação e cruzamento de experiências entre os diferentes grupos de mulheres. A circulação de imagens entre coletivos e atores demonstra que existe uma forma de protestar, mas essa forma não é fixa, vem da memória do que significa agrupar, mover, rebelar e resistir e que é atualizada a cada evento, seja em razão do lugar, do tema, de atores ou da época. O 
repertório dos protestos é composto por elementos modulares, que são reconhecidos em protestos e manifestações em diferentes locais, grupos e períodos, mas que são adicionados de símbolos e características locais.

As visualidades e estéticas registradas em nosso trabalho, demonstram que os grupos organizados e as mulheres autoconvocadas utilizam-se de formas visuais herdadas de outros movimentos de ação coletiva, mas que inventou novas (Tilly, 2008), de acordo com as experiências de vida e as bandeiras que defendem. Tilly (2008) afirma que não é possível existir duas performances contenciosas que se espelham perfeitamente, os participantes improvisam, interagem com outros participantes e, nesse processo é que as pequenas inovações são elaboradas. Algumas inovações desaparecem, mas outras se tornam permanentes e passam a fazer parte de seus repertórios e, até mesmo, incrementam repertórios de outros movimentos.

É possível afirmar que existe transnacionalidade dos repertórios que, a exemplo do lenço, que em nossos registros aparece confeccionado em chita demonstrando a mistura de visualidades feministas latino-americanas com elementos que evocam a brasilidade e o popular. Os eventos analisados permitem afirmar que há o cruzamento de agendas e a busca pela união de marchas, demonstrando que há ligações entre movimentos nacionais e locais. A presença da exposição do corpo e seu uso como principal instrumento de comunicação também marca as visualidades. $\mathrm{O}$ ato de insistir em aparecer nos lugares em que se costuma apagar determinados grupos é uma das formas em abrir frestas na esfera da aparência e, nesses casos, produzir visualidades a partir de uma estética que evidencie identidades, se torna repertório.

A multiplicidade estética e visual coincide com os diferentes feminismos da contemporaneidade e com as diferentes pautas que são transversais ao movimento, portanto, é possível admitir que não se tratam de maneiras unificadas de se protestar. A liberdade, segundo Butler (2018) é frequentemente exercitada com outras pessoas, mas essa aliança "não exatamente presume ou produz uma identidade coletiva, mas um conjunto de relações possibilitadoras e dinâmicas que incluem suporte, disputa, ruptura, alegria e solidariedade (Butler, 2018: 32). São elementos visuais que indicam permanências e transformações nos repertório dos movimentos sociais e nas suas formas de protestar.

\section{REFERÊNCIAS}


ARENDT, Hannah. A condição humana. 10. ed. Rio de Janeiro: Forense Universitária, 2009.

BERTOLACCINNI, Luciana Maria. Política de las corporalidades: placer, dolor y memoria en protestas sociales feministas de Rosario (2015-2017). Perspectivas Revista de Ciencias Sociales. Año 5 No. 9 Enero- Junio 2020, pp. 8-31. Disponível em: https://perspectivasrcs.unr.edu.ar/index.php/PRCS/article/view/148 . Acesso em 04 de janeiro de 2021.

BUTLER, Judith. Corpos em aliança e a política das ruas: notas para uma teoria performativa de assembleia. Rio de Janeiro: Civilização Brasileira, 2018.

DIDI-HUBERMAN, Georges. Levantes. Catálogo de exposição. São Paulo: SESC Pinheiros, 2017.2 Disponível em: https://issuu.com/sescpinheiros/docs/levantes completo issu. Acesso em 17 de fevereiro de 2021.

DIEGUEZ CABALLERO, Ileana. Encarnaciones poéticas. Cuerpo, arte y necropolítica. Athenea Digital, 18.1 (2018): 203-219). Disponível em: https://atheneadigital.net/article/view/v18-n1-dieguez/2250-pdf-es Acesso em 19 de março de 2021.

Documento final da Marcha das Mulheres Indígenas: Território: nosso corpo, nosso espirito. Agosto de 2019. Disponível em: https://cimi.org.br/2019/08/marcha-mulheresindigenas-documento-final-lutar-pelos-nossos-territorios-lutar-pelo-nosso-direito-vida/

Acesso em 21 de fevereiro de 2021.

GOMES, Carla; SORJ, Bila. Corpo, geração e identidade: a Marcha das vadias no Brasil. Sociedade e Estado, Brasília , v. 29, n. 2, p. 433-447, Agosto de 2014. Disponível em $<$ http://www.scielo.br/scielo.php?script=sci_arttext\&pid=S0102$69922014000200007 \& \operatorname{lng}=$ en\&nrm=iso $>$. Acesso em 21 de fevereiro de 2021.

GUZZO, Morgani; WOLFF, Cristina Scheibe. Afetos no engajamento político das Marchas das Vadias no Brasil (2011-2017). Revista Estudos Feministas, Florianópolis, v.28, n.2, e72429, 2020.

Disponível

$<$ http://www.scielo.br/scielo.php?script=sci_arttext\&pid=S0104-

em 026X2020000200603\&lng=pt\&nrm=iso>. Acesso em 21 de fevereiro de 2021.

JASPER, James M. Protesto: uma introdução aos movimentos sociais. Rio de Janeiro: Zahar, 2016.

MIRZOEFF, Nicholas. $O$ direito a olhar. ETD - Educação Temática Digital, Campinas, SP, v. 18, n. 4, p. 745-768, nov. 2016. ISSN 1676-2592. Disponível em: $<$ https://periodicos.sbu.unicamp.br/ojs/index.php/etd/article/view/8646472>. Acesso em 09 de abril de 2019.

RANCIÈRE. Jacques. O Dissenso. In: NOVAES.A. A Crise da Razão. São Paulo: Companhia das Letras, 1996.

RANCIÈRE, Jacques. A partilha do sensivel: estética e politica. São Paulo: Editora 34, 2009. 
TARROW, Sidney. O poder em movimento: movimentos sociais e confronto político. Petrópolis: Vozes, 2009.

TILLY. Charles. Regimes and repertoires. Chicago: University of Chicago Press, 2006.

TILLY, Charles. Contentious Performances. New York: Cambridge University Press, 2008 .

TILLY, Charles; WOOD, Lesley J. Los movimientos sociales, 1768 - 2008: desde sus orígenes a Facebook. Barcelona: Crítica, 2009.

Recebido: $22 / 03 / 2021$

Aprovado: 02/06/2021 